\title{
Kanamycin の腎毒性に関する生化学的研究
}

\author{
慶応義熟大学医学部泌尿器科学教室 中 薗 昌 明
(主任教授 : 大越正秋) \\ BIOCHEMICAL STUDIES ON NEPHROTOXICITY OF KANAMYCIN
}

\author{
Masaaki Nakazono \\ Department of Urology, School of Medicine, Keio University
}

(Director: Prof. M. Ohkoshi)

It has been shown that nephrotoxicity of kanamycin is enhanced when administered with low molecular weight plasma expanders. Release of lysosomal enzyme ( $\beta$-glucuronidase) in vitro, and release of soluble enzyme (lactic dehydrogenase) into blood stream were taken as the indicators of tissue damage caused by administration of drugs in this study.

Five groups of female albino rats weighing 180 to $200 \mathrm{~g}$ were treated by 1) dehydration, 2) dehydration and kanamycin* (abrv. Km), 3) dehydration and low molecular weight dextran (abrv. Dxt, $50 \mathrm{ml} /$ $\mathrm{kg}$ of $10 \%$ solution), 4) dehydration, $\mathrm{Km}$ and Dxt, or 5) dehydration, $\mathrm{Km}$, Dxt and hydrocortisone.

$\beta$-Glucuronidase study: Activity of the enzyme was measured in the supernatant fraction of tissue homogenate obtained by mechanical destruction and centrifugation, and in the medium containing the enzyme released from the lysosomal fraction during incubation at $37^{\circ} \mathrm{C}$. Both experiments showed that the release of $\beta$-glucuronidase was most marked in group 4). The activity in groups 2), 3) and 5) was statistically lower than that in 1). These data indicated that the combination of $\mathrm{Km}$ and Dxt more labilized the kidney lysosome than the administration of either drug alone did, and that hydrocortisone partly restored the labilizing effect of these drugs.

Lactic dehydrogenase (LDH) study: 1) Serum LDH level was not increased by dehydration alone. Dxt caused a rapid and short-term rise. However, combination of Dxt and $\mathrm{Km}$ showed a gradual longlasting increase of serum LDH activity. Cortisone incompletely inhibited the increase. 2) Kidney fraction of LDH (absorbed on DEAE cellulose) showed about $50 \%$ of the total activity on the average 6 hours after treatment with the combination. With Dext alone, only a few per cent of the total was absorbed on DEAE cellulose, indicating that most LDH in serum was released from the liver. Cortisone did not affect the ratio of fractions greatly. 3) Electrophoretic separation of LDH isoenzymes showed that LDH-5 was dominant in the serum from animals treated with Dxt. However, in the animals treated with the combination, 5 bands (from LDH-1 to LDH-5) were visible. Cortisone did not affect the released isoenzyme pattern.

\author{
序論 \\ 化学療法施行に当つては, 種々の副作用の発現に留意 \\ しつつ投与量, 間隔, 期間等を決定, あるいは変更して \\ いくのが常識である. 泌尿器科領域は感染症, 特に腎盎 \\ 腎炎に於ては感染腎自体が既に機能不全を起こしてい \\ て, 両側性疾患の場合に薬剤の排泄遅延（体内蓄積をま \\ ねく事，感染腎の既存の病変自体が薬剤の毒性に対する \\ 感受性を高めている事) 等, 一面では感染症治療に有利 \\ にみえながら，他方その副作用発現が促進されている場
}

合がある(1) 6). その為, 腎毒性を有する事が判明している polyenemacrolide 系薬剤 (amphotericin B nystatin 等 $)^{7) ~ 10)}$, poly peptide 系薬剂 (polymyxin B または colistin) ${ }^{11) ~ 18)}$, aminoglycoside系薬剤 (streptmycin, kanamycin, neomycin, gentamicin, kasugamycin 等）の使用に当つては使用前に総腎機能の低下の無い 事，使用期間中の腎機能は低下の無い事が，薬剤通常量 の使用に当つての 条件であり，また腎機能低下の存在 する時は，その低下の程度に応じた投与量の決定が行な 
われる。しかし最近, kanamycin とある種の plasma expander との併用時治い腎障害が起こる事が明らか になつて来た. Kanamycinを初めとする aminoglycoside 系抗生剂が，第怔脳神経に対する毒性，抢よび腎 に対する毒性を有する事は周知の事であるが，腎に対し ては大量に使用するか，あるいは既存の腎疾患を有する 患者飞長期間連用せぬかぎり，重篤な腎不全を起こす事 は稀である。しかるにここ 2,3 年来 kanamycin と低 分子デキストラン，あるいは algin 酸ソーダとの併用 時に高率に急性腎不全のみられるとの報告が相次ぎ，臨 床例の検討 ${ }^{27) ~ 331}$ 拈よび実験的検索 ${ }^{34)}$-37) が広くなされ つつある.これらは形態学を主としたものであり, それ らの報告によれば, 光学顕微鏡を用いた観察では，近位尿 細管の高度の空胞状变性が主な变化で, 時に遠位尿細管 にも同様のものが認められている。この空胞は, 電子顕 微鏡的には, 明膫な限界膜を有せず, 空胞中は低分子デキ ストランと思われる小顆粒で充たされている。また，細 胞質内に技そらく lysosome を中心として出来たと思わ れる，不正形の密度の高い部分が認められるとしてい る ${ }^{38) \sim 40)}$. この様に 形態学的観察はかなり進んだ点まで 行なわれてはいるものの, この様な形態学的変化に伴う 機能的変化については不明な点が多い。また，さらに一 歩進んで個々の細胞機能の変化, あるいは細胞内 organelle の機能的変化もこの種の現象の解析当つては検 討を要するものである. 著者は今回この点について生化 学的方法論により検討を加兄てみた。まず白単の腎皮質 部分の lysosomal enzyme の代表として $\beta$-glucuronidase をとりあげ，核酵素の lysosomal membraneか らの遊離について検討した. さらに cytoplasmic enzyme の血清中へ遊離するものの代表として lactate deheydrogenase（以下 LDH と略す）をとりあげ，その 活性打よびその isoenzyme の pattern の変化につい て検討を加えてみた．その結果，この様な低分子デキス トラン投与時にみられる浸透圧性腎症を基盤とし, 抗生
剂投与により発症する急性腎不全の診断上，LDH が有 力な指標として使用し得る事が判つた。

\section{実験材料及び方法}

実験動物としては 180〜 200 gのウイスター系雌の学 を使用した。

すべての動物は実験に際して72時間 の脱水期間をお き,その間24時間毎に kanamycin を一定量, 腹腔内に投 与し, 脱水72時間目に低分子デキストランとkanamycin を腹腔内に投与した．脱水期間中は飼料は自由に与兄 25 $\sim 26^{\circ} \mathrm{C}$ 定温に保つた. 実験動物は処理の方法により下 記のごとく 5 群に分類した。

第 1 群 脱水群

第 2 群 脱水+Kanamycin 投与群

第 3 群 脱水 + Dextran 投与群

第 4 群 脱水+Dextran+Kanamycin 投与群

第 5 群 脱水+Dextran + Kanamycin + Cortisone acetate 投与群

Kanamycin, 硫酸カナマイシンを $10 \mathrm{mg} / \mathrm{ml}$ になる様 生食水にて溶解し， $300 \mathrm{mg} / \mathrm{kg} / \mathrm{day}$ の割合にて腹腔内に 投与した。

Cortisone acetate, $25 \mathrm{mg} / \mathrm{kg} /$ day の割合に筋肉内投 与した.

低分子 dextran，大五栄養社製の平均分子量約 40,000 のものを $50 \mathrm{mg} / \mathrm{kg}$ の割合で腹腔内投与した.

動物は低分子 dextran 投与後12時間目に屠殺した。 但し第 4 群，执よび第 5 群では，dextran 投与後 12 時間 目にさらに kanamycin $300 \mathrm{mg} / \mathrm{kg}$ 㧊よび, kanamycin $300 \mathrm{mg} / \mathrm{kg}$ と cortisone acetate $25 \mathrm{mg} / \mathrm{kg}$ それぞれ投与 し，30分後に屠殺した。

腎ホモジネイトの調製は Weissmann \& Thomas $^{42)}$ に 従い，次に示す方法で行なつた。

すなわち0.25M蔗糖溶液にてほぼ10\%腎ホモジネイト を調製し，それを $800 \times 810$ 分間 $5{ }^{\circ} \mathrm{C} て ゙$ 遠沈し，細胞残 渣执よび核を含む沈渣は廃棄した。上清部分はさらに,

表 1 Activity of Beta-glucuronidase in rat kidney

\begin{tabular}{c|c|c|c|c|c}
\hline & group 1 & group 2 & group 3 & group 4 & group 5 \\
\hline Unsedimentable & $616 \pm 114$ & $1430 \pm 192$ & $1364 \pm 252$ & $1692 \pm 252$ & $1110 \pm 281^{\sim}$ \\
\hline Incubated & $231 \pm 27$ & $339 \pm 23$ & $293 \pm 140$ & $638 \pm 120$ & $347 \pm 198 \sim$ \\
\hline
\end{tabular}

(units/wet. g sample)

( $\sim$ Difference from group 4 significant at $\mathrm{P}>0.001$ ) 
図 1 Fractionation scheme for rat kidney granules

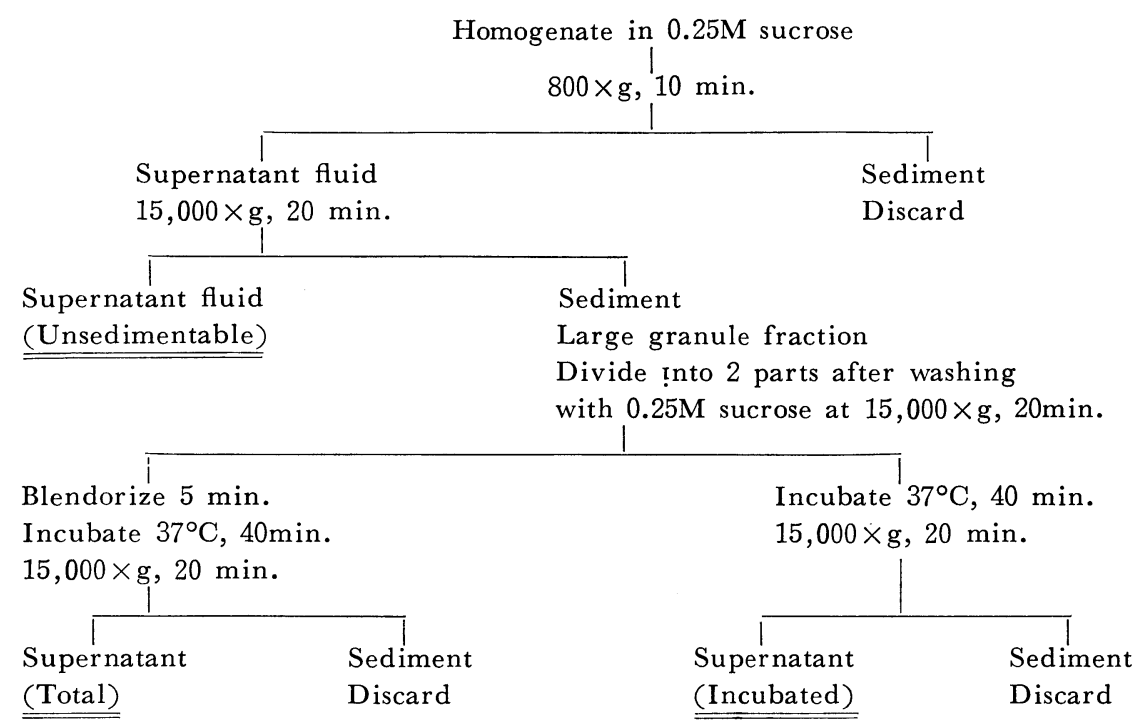

from the method of Weissmann and Thomas.

$15,000 \times g$ 20分間遠沈し，その上清部分を unsedimentable fraction として用いた. 沈椬 (lysosomal fraction）は0.25Mの蔗楉溶液で一度洗浄後二分し，その一 方を 5 分間ブレンダー処理した 後 $37^{\circ} \mathrm{C} 40$ 分間 incubałe して充分酵素をlysosome の膜面より遊離させ，その $15,000 \times g$ 20分遠沈上清を, 酵素の全活性を測定する為 に供した. 残りの部分は $0.25 \mathrm{M}$ 蔗糖溶液に再浮遊後 $37^{\circ} \mathrm{C}$ 40分 incubate し，その15,000× g 20 分遠沈上清を溶出 部分 (incubated) とした。

酵素活性の測定法

i) $\beta$-glucuronidase

$\beta$-glucuronidase の活性測定は Fishman, Springer 特よび Bernetti ${ }^{43)}$ の方法に従つた。 Phenolphthalein glucuronideは中外製薬より発売されているものを使用 し, units/wet, g sample で活性を表現した.

ii）血清中 LDH 活性測定は Bergmeryer, Bernt 抒 よび Hess'年) の方法に従つた。

Reduced diphosphopyridine nucleotide (DPNH) Sodium Salt (DPNH- $\mathrm{Na}_{2}$ ) は Sigma 社のものを使 用した。腎臓型一 $\mathrm{LDH}$ (主としてLDH 拈よびLDH $_{-2}$ ) と肝蔵型一LDH (主として $\mathrm{LDH}_{-5}$ 预よび $\mathrm{LDH}_{-4}$ ) と の分画は $\mathrm{Hess}^{45)}$ の方法に従つた。

すなわち，血清を $2 \times 10^{-2} \mathbf{M}$ 燐酸緩衝液（pH 6.0） $1,000 \mathrm{ml} に 3 \mathrm{ml}$ の割合で氷室内にて 2 時間以上透析

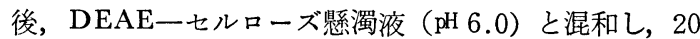
分間 $4{ }^{\circ} \mathrm{C}$ に保ち，腎蔵型一LDH をDEAE セルローズ 汲着させた後, 約 4,000× g 5 〜10分遠沈し, DEAE 一セルローズを除き，その上清に残つた活性を肝臓型一 $\mathrm{LDH}$ 活性として測定した。腎藏型一 LDH 活性は DE $\mathrm{AE}$ 一七ルローズ処理前の全活性より，肝臓型活性に差 引いて算出した。

DEAE一セルローズは生化学工業発売の（DEAE一 TLC)を使用した。

電気泳動は菅野の方法 ${ }^{46)}$ 亿従つた。また支持体として は cellogelを使用した。

デンシトメーターはアタゴの Quick Densitomaster を使用した。

\section{結 果}

第 2 図は腎皮質部分 unsedimentable fraction (lysosomal membraneより溶液中に遊離したと思われる) $\beta$-glucuronidase 活性をプロットとしたものである. Kanamycin 投与群 (第 2 群), dextran 投与群 (第 3 群), dextran+kanamycin 投与群 (第 4 群) および dextran+kanamycin+cortisone acetate投与群（第 5 群）はすべて脱水のみ注どこした第 1 群に比較し強い活 性を示している.

第 4 群と cortisone acetate を併用した第 5 群では危 険率 0.001 で有意差が認められた。しかし第 2 群，第 3 
図 2. The activity of $\beta$-glucuronidase (unsedimentable)

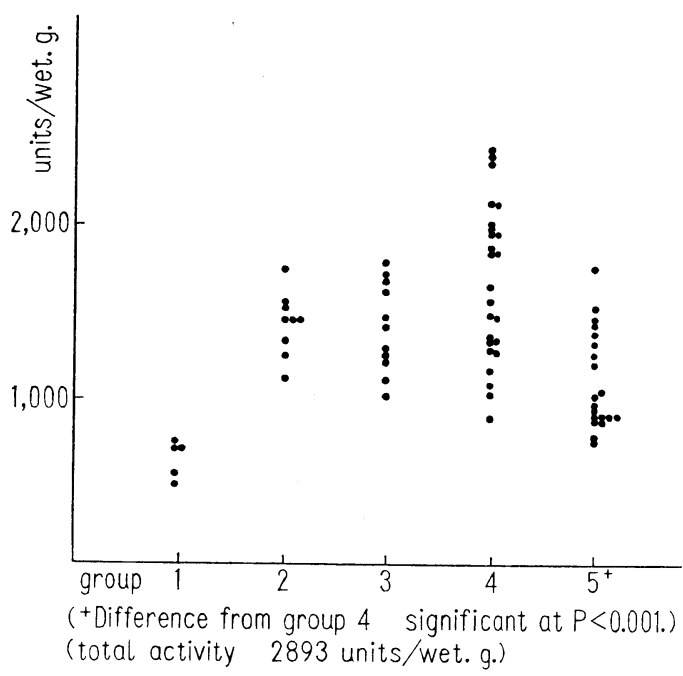

群，第 4 群の間には有意差は認められなかつた。

第 3 図は $37^{\circ} \mathrm{C} 40$ 分間 lysosomal fraction $0.25 \mathrm{M}$ 蔗 糖溶液にて incubation 後, 15,000× g20分遠沈した上 清部分の $\beta$-glucuronidase 活性 (incubated) を示す ものである。この実験系に於ても，第 2 図と同様の傾向 を示しているが，第 4 群の活性が他の 4 群に比較し明ら かに高い事は注目に值する。特に cortisone を併用した 第 5 群の活性值と, 第 4 群のそれを比較すると著明な差 異が認められる。第 2 群は活性值は殆んど同一であつた が，第3群の々れはすこしバラッキが大きかつた。第 3 群と第 5 群では有意差をみなかつたが，第 4 群と第 5 群 でけ推計上 $\mathrm{P}=0.001$ で有意の差を認めた。

第 1 群より第 5 群に於て, 該酵素の総活性值 (total) にはみるべき変化が無かつた。

第 4 図は第 3 群，第 4 群和よび第 5 群の血清中の LD H活性を経時的に検討したものである．図の原点は72時 間脱水後， dextran を投与した時点を示している。

72時間の脱水のみでは血清中の $\mathrm{LDH}$ 活性にはみるべ き変化が無かつた。しかしながら dextran の投与は短 時間のらちに急速な $\mathrm{LDH}$ 活性の上昇をもたらしてい る。

第 4 群は初めの 6 時間で急速な活性上昇をみ，その後 はゆるやかに下降している，第 5 群は12時間目までゆる やかに上昇し，その後はあまり大きな変化を認めない． 第 3 群は30分值で，ある程度急速な上昇をみせた後，緩 慢な変化を示しているにすぎない。
図 3 . The activity of $\beta$-glucuronidase(incubated)

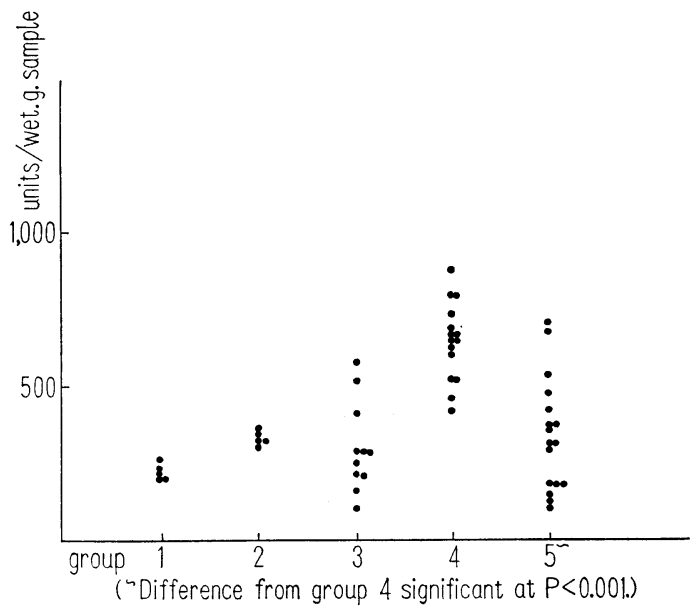

図 4. The total activity of serum $\mathbf{L D H}$

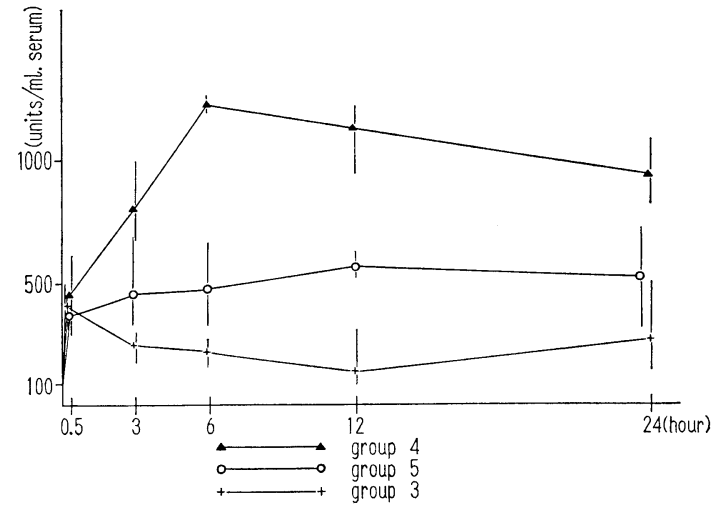

図 5. The percentage of kidney-LDH-activity

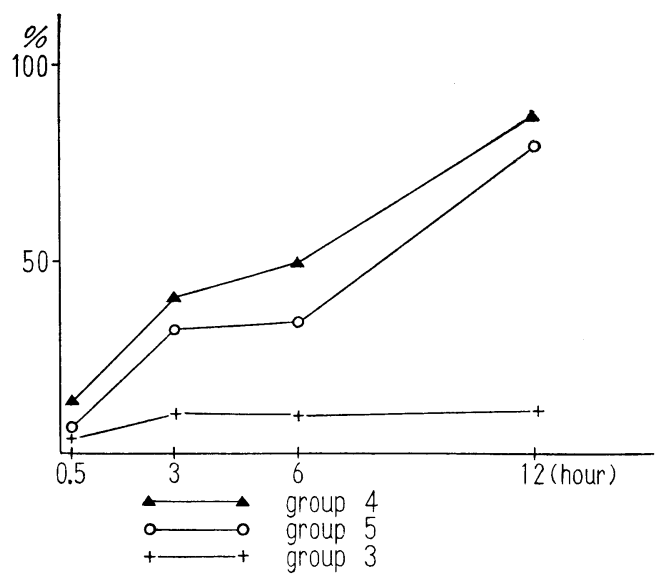


圀 6

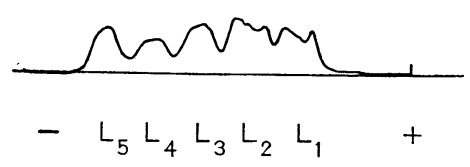

Kanamycin+Dextran $300 \mathrm{mg} / \mathrm{kg} /$ day

Dextran 投与後 6 時間目の血清を使用した.

図 7

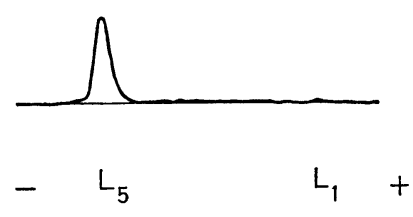

Dextran alone $50 \mathrm{ml} / \mathrm{kg}$

dextran 投与後 6 時間目の血清を使用した。

各群の差を概観すると血清中の LDH 活性の比較に於 てもcortisoneを併用した第 5 群が，第 4 群(kanamycin +dextran)よりも有意の差で低く， $\beta$-glucuronidase の活性比較の場合に相応した傾向がみられた。

第 5 図は血清中の LDH をHess の方法に従い腎䁍型 $-\mathrm{LDH}$ と肝蔵型一 $\mathrm{LDH}$ に分画し，その腎臓型- $\mathrm{LDH}$ 活性が全 LDH 活性に対する百分率を経時的に検討した ものである。

第 4 群，第 5 群ともほぼ同様な変化を示している. 第 3 群では腎藏型一LDH は経時的には殆んど変化を認め ない, dextranのみでは腎実質に対する障害は低い様に みうけられる。

一方 kanamycin を dextran と併用する場合は， cortisone の使用の有無にかかわらず，腎臓型一LDH のしめる割合が経時的に増強している。第 7 図は kanamycin, dextran 併用群の dextran 投与後 6 時間目の 血清 LDH の isoenzyme のデンシトグラムである. $\mathrm{LDH}_{-1}$ より $\mathrm{LDH}_{-5}$ まですべてのピークが明瞭に認め られる。

第 6 図は第 3 群の血清 LDH の isoenzyme のデンシ トグラムである． $\mathrm{LDH}_{-5}$ のピークが明瞭に認められる が，第 4 群でみられた $\mathrm{LDH}_{-1} \mathrm{LDH}_{-2}$ のピークは認め られない。

\section{考按}

a ）白単腎皮質部分の $\beta$-glucuronidase について Shibko および Tappel ${ }^{41)}$ の報告によれば $\beta$-gluc- uronidase は他の lysosomal enzyme に比較し，腎皮質 部分に強い局在を示すと同時に, 種々の細胞分画に於る 活性に於ても, arylsulfataseの16\%, acid ribonuclease の17\%, acid phosphatase の16\%に比較し，60\%と一 段之強い局在を lysosomal fraction に示している. そ れ故今回の実験では該酵素を lysosomal enzyme の代 表とした。

Kanamycin の腎毒性については，1958年以来臨床例 に関するもの ${ }^{20121)}$ ，および薬理学的実施に関する報告 等 ${ }^{47) ~ 49)}$ 種々の報告がなされて来た. 臨床的に政障害発生. の有無をみる parameter としては, 糸球体濾過值の減 少，尿細管機能の低下，蛋白尿の出現，顕微鏡的血尿等

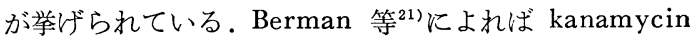
だけの投与により乏尿，BUN の上昇，および組織学的 に急性腎不全の像を呈した症例のあつた事を報告して いる. Kleeman 等 ${ }^{22)}$ は家鬼を用い kanamycin $100 \mathrm{mg} /$ kg/dayでは腎障害の症候を認めなかつたが，100～ 200 $\mathrm{mg} / \mathrm{kg} / \mathrm{day}$ では近位尿細管壊死の起こる事, さらに200 $\mathrm{mg} / \mathrm{kg} /$ day の場合は蛋白尿, 血尿, 窒素血症, 時とし て無尿を来し，組織学的には近位，および遠位尿細管壊

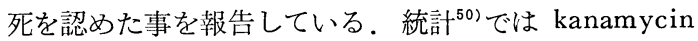
25 $50 \mathrm{mg} / \mathrm{kg} /$ day の割合で人体に投与された場合，10 \%に蛋白尿の出現が，20\%に顕微鏡的血尿がみられると いう。また，顆粒円柱および硝子様円柱の出現する場合 も報告されている。

次に dextran は1945年 Grönwall ${ }^{51)}$ と Ingelman ${ }^{52)}$ によつて初めて臨床的に応用された代用血浆で，今日 まで広く臨床に用いられて来たグルコース多糖体で, $\alpha-1-6$ 結合で主鎖を形成し，全体の約10\%は $\alpha-1-3$ 結合 で分岐，側鎖を出しており，生体内に生理的に存在する 糖原物質とは異なつている. 現在本邦で一般的に使用さ れている臨床用 dextran 製剂は, 平均分子量約70,000 の高分子 dextran と称されるものと, 約 40,000 の低分 子 dextran と称されるものの 2 種類である。本製剤の 投与に当つてはまず問題となる事は，本物質の生体内で の消失過程であろら。生体内に投与された dextran は 大部分腎によつて生体外に排泄されるものと桨兄ら机て いるが，高分子のもの程完全でない様である ${ }^{53) 54)}$. 従つ て，本製剤の大量運続投与により， dextran が生体内 に蓄積された後, 細胞内で分解代謝される事により消 失する過程が想像され，ある程度は確認もなされてい $3^{55) ~ 57)}$. 従来 dextran の生体内蓄積に関しては実験的 に数多くの研究が試みられているが，人体例での詳細な 
検索は極めて数少く, Johnston ${ }^{58)}$, Zettergren ${ }^{59)}$, Vicker $\mathrm{y}^{60)}$ ，Traenckner ${ }^{61)}$ 扩よび小島等の報告をみてい るにすぎない，従つて現在のところ，人体内に打壮る dextran の蓄積拉よび消失過程に関する正確な検討は充 分とはいい難い様に思われる。

小島等の報告によれば，人体に投与された dextran を全身各所の網内細胞が活発に摂取して胞体内に蓄積 し, 細胞自体は著しく腫大し，この様な網内系細胞の系 統的腫大が腎に括ける变化と並んで蓄積現象の基本的な 変化であるとしている。腎臓の変化とは，糸球体メサン ギニウム汇認められる膨化と肥厚，扤よび稀に系球保蹄 にみられる細血管内皮に由来する少数の泡洙細胞等のび まん性ないし限局性の空胞変性である。この変化が高度 な場合，Henle 係蹄，さらに遠位曲尿細管にまでおよ び，また稀に Bowmann 囊の上皮細胞にも空胞变性と腫 大を認める事がある。一般に尿細管の空胞変性の程度は dextran の総投与量に左右されるが，最終投与後の経 過日数とも密接に関連し, 時期の経過に伴い漸次消裉の 過程をたどる様である。また尿細管上皮細胞の変化は混 濁腫脹の程度から胞体内細管形成, 微細空胞の出現, 粗大空胞化を認めるまでに到る。一方動物実験では我 々の教室の木村 ${ }^{33)} か ゙ ， （ 1 ）$ 片側腎動脈結紫, 再開放,

（2）片側尿細管血禁，（3）脱水等, 種々の条件下で 実験し，前期の人体例に护けると同様な変化を得ると 同時に，電子顕微鏡を用いて lysosome 由来と思われる 不正形の密度の高い部分の存在する事を, Tramp \&

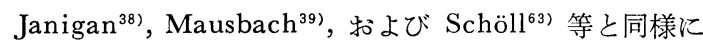
認めている。これらの所見より著者は, 上記の変化を一 種の急性腎不全の準備状態（何らかの機転が加われば急 性腎不全に移行する様な状態）になり得ると考兄，今回 の抗生剂を用いた実験的急性腎不全の作製に応用した。

Lysosomal membrane の種々の酵素の遊離に関して は, de Duve 等の詳細な報告があり,それらによつて lysosomal membrane が水解酵素の活性化に重要な役 割を果している事が明らかにされた ${ }^{64)}$. 彼等は凍結, 粉 砕等の機械的破壞, 渗透圧の变化, 表面活生剂, 分解酵 素, ビタミン $\mathrm{A}, \mathrm{D}, \mathrm{E}$ 等, 種々の方法によりlysosomal membrane より種々の水解酵素を遊離する事に成功し ている(2)65) フ71).

Kanamycin の lysosomal enzymeの遊離作用関す る報告は T. Ishii，D. Ishii 括よび K. Balogh TR ${ }^{72)}$ による内耳に於ける報告をみているが白単腎 lysosome については未だ報告をみていないようである。 de Duve 等は彼等の一連の実験より, 酵素は多少の 相違はあつたにしても，ほ注同一様式により膜面より遊 離すると考光ている ${ }^{69}$. すなわち, 酵素は半透過性の膜 に扮扮われた震内に含まれて拈り，膜の透過性の変化に より, 襄内より遊離して来るといら仮説を提出した。こ れに対し Koenig 拈よび Jibil ${ }^{73)}$ は，本来水解醭素は イオン結合により lysosomal membrane の構成物質の 一つである糖脂質と結合して括り，何らかのイオンの変 動により，この結合が離解する事によつて遊離するとい ら仮説を提晿している。

今回の実験では著者は kanamycin がいかなる条件， およびいかなる機序により腎皮質部分の lysosomal membraneより $\beta$-glucuronidaceを遊離させたのか，ま た少くとも遊離し易い状態にさせたのか，またdextran がいかなる条件を lysosomal membrane に与えたの か，それらの事に関し明瞭な説明を与え得なかつたが， 少くとも脱水時に投与された dextran が何らかの作用 を lysosomal membrane に扣よぼし，膜面の性状を変 化させ，その上に kanamycin が相加，または相乗的に 㗢いて変化を膜面に起こさせたと考えている．何れにし 万 dextran と kanamycin の作用が質的に異なるもの か否かを何らかの方法で決定する必要がある事は明らか であろら。

Dextran の投与のみでは $\beta$-glucuronidase 活性に 大きな変化をみなかつた事から考光てみても，また de$\mathrm{xtran}$ の構造から考光ても, 細胞内に摂取されたdextran が腎細胞内の $\mathrm{pH}$ をさく变化させる事はない様に思われ る.一方 de Duve 等の言う様な半透過性膜に㧍おわれ た一つの袋を考えた場合, 細胞内に摂取された dextran により起こる現象は渗透圧の変化等幾つかあると考兄ら れるがその現象だけでは酵素の遊離は起こらず，一つの 準備状態を形成するだけに止まつていると考えられる。 何故なら dextran は脱水時以外でも腎細胞内に摄取さ れ，また脱水時であつても，その事が酵素の遊離 と結 び付かないからである. 浸透圧による影響については Shibko \& Tappel ${ }^{41)}$ の報告があるが，それによれば 腎 lysosome は肝のそれよりも溶媒の浸透圧による影響 に対し抵抗性が強いとされている。また今回の実験で dextran 抢よび kanamycin の投与により生体内に於 て既に $\beta$-glucuronidase が lysosomal membrane よ り遊離していたのか，または単に遊離し易い状態になつ ていたのかについては，はつきりした解答を得るには到 らなかつた。何故なら今回の実験では確かに incubation 
により他の群に比較し第 4 群が高い活性を示してはいる が，生体内と生体外では䤃素の動きに大きな相違がみら れる事から考えてみても，簡単に結論は出来ない様に思 われる。

病的に膨化した lysosomal membrane は非常にもろ く, 酵素はホモジネイトの調整の間や, 組織分画中に溶 媒中に遊離してしまつている事は充分考兄られる。この 点に関してさらに究明しょらとすれば，腎の潅流実験が 必要であろう。

Cortisone acetate の酵素の膜面からの遊離阻害作用 (stabilizer 作用) は Weissmann \& Thomas ${ }^{42)}$ の白単 肝に於ける実験と同様, 著者の実験に於いてもstabilizer 作用を示した

b) 血清中の Lactate dehydrogenase について 生体内に於いて蔵器の破壊的病変の際にみられる血清 中の種々の酵素活性の変化については, 1954年La Dae, Wroblewski 抢よび Korman ${ }^{76}$ が急性心筋硬塞の際 $飞$ glutamic oxaloacetic transaminase (以下 GOT と 略す）の血清中の活性上昇のみられる事を報告して以 来, Nydick ${ }^{77)}$ 等の実験により, 蔵器破壊の程度とよく 相関する事が確認された，急性腎不全時の血清中の諸醭 素の活性上昇については1959年 $\mathrm{Kemp}^{78)}$ による, GOT p glutamic pyruvic transaminase (以下 GPT と 略す）等について阻血腎を用いた実験がある。Kemp によれば腎をトルェンや生理的食塩水で潅流した際， GOT はアルカリ phosphatase (以下 Alk-p と略す) および GPT よりもずつと早く腎より流出し，また阻血 腎の血流を再開した場合でも GPT，Alk-p は流出をみ ないにもかかわらず，GOT はやはり活性上昇が認めら れたとしている. 以上の様に同じ cyto-plosmic の酵素 であつても，その動きは一様でない。また腎疾患に於け る LDH の変動については, White ${ }^{79)}$ が系球体腎炎の 患者で GOT 活性の上昇がみられないにもかかわらず $\mathrm{LDH}$ 活性の上昇を示した症例を報告したのが最初であ ると思われる。また Wacker，Ulmer 㧊よび Valee ${ }^{80)}$ は慢性系球体腎炎による, “単純な” 尿毒症の場合には LDH 活性の上昇はみられないのに反して，腎硬塞拈よ び亜急性系球体腎炎の場合には該酵素の活性上昇が認め られた事を報告している。一方1958年 West, Zimmer$\mathrm{mann}^{81)}$ は，その論文に於いて,1） 血清LDH活性の上 昇は窒素血症の程度とは直接相関々係が無い事，2）尿 管結紮拉よび脱水等の条件では LDH 活性の上昇をみる とは限らない事，3）腎疾患患者ではGOT 活性の上
昇をみる事は非常に稀である事を報告している。また $\mathrm{Kemp}^{82)}$ 等は馬杉腎炎および出血性ショックの際 $\mathrm{LDH}$ 活性の上昇がやはりみられる事を報告している，著者は これらの報告から Nielsen ${ }^{83)}$ の言つている様に，慢性腎 不全に於いては腎組織の破壊は通常緩慢である為，腎よ りたとえ LDH が遊離されたにしても測定出来る程の変 化として現われて来队事は当然で，この事は肝疾患に於 いても同様と思う．急激な組織崩壊をみる場合のみ血清 中の酵素活性上昇をみるとするのが当然であろら，糸球 体腎炎の乏尿期，または腎障害に於ける血清 LDH 活性 の上昇は，腎組織の膜透過性の変化，あるはは広沉な組 織壊死によるものと考えられるが，この様な場合腎以外 の組織（藏器）からどの程度 $\mathrm{LDH}$ が血清中に遊離して 来るかが問題になるのは当然である.

この点 LDH は臓器によりその isoenzyme のパタ ーンに明瞭な相違のみられる点，および比較的簡単に isoenzymeを分離出来る点で marker enzyme として適 当であると考えられる。

一方小島等 ${ }^{62}$ によれば dextran は生体内に投与され た場合，肝臓に到達すると類洞内で kupffer 星細胞に よつて摂取され，その結果，該細胞は泡洙状に腫大し増 生する。 Mowvy おょび Millican 法 PAS 反応では 泡洙細胞内に多量の PAS 顆粒が証明されるほか, 肝細 胞内にも同種類の顆粒が認められ，一方泡沫細胞が 部 位によつては多数群在し時に肉芽様增殖を示す為，類洞 は著しく拡張, 肝細胞は変性, 萎縮し一部消失する所見 が認められたが，Traenkner ${ }^{84)}$ が報告している様な肝 実質の小壞死，ならびに好中球，大単核細胞の浸潤巣は 認め得なかつたとしている。また一方West ${ }^{85)}$ はdextran はある種の単に対しアナフランクトイド反応を起こし， 且つそれが遺伝因子によつて左右される事を報告してお り, 松本等 ${ }^{86)}$ はアナフランクトイド反応に際して血清中 に肝臓型 LDH が多量に遊離される事をみいだしてい る。以上の点より白単に dextran 単独に投与した場合 （第 3 群）にみられた $\mathrm{LDH}_{-5}$ の上昇は肝臓由来のもの と考劣て差支光は無いであろう。

腎臟と同じ様な LDH isoenzyme を有する臟器とし て心筋があげられるが，心筋に対する dextran の作用 は小島等 ${ }^{64)}$ の報告によれば, 心外膜, 殊に脂肪組織の毛 細管周囲，および心筇間質にも泡洙細胞が散見せられた が，大きな組織壊死および変性はみられなかつたとして いる. 今回 dextran kanamycin 併用群（第 4 群）の $\mathrm{LDH}_{-1}$ 打よび $\mathrm{LDH}_{-2}$ は腎藏に由来すると仮定出来る 
のではないだろらか.

DEAE一七ルローズによる肝蔵型と腎蔵型の分画に よる方法と，電気泳動汇よる isoenzymeの分離による方 法とでは若干量的相違がみられる。これはDEAE一七ル ローズによる分画では腎臟型 LDH は，DEAE一七ル ローズに完全に肝臓型 LDH が吸着されずに残ったとも 考光られる。西るいは透析 の際の透析液の量が脱水に より蛋白濃度が上つている血清に対しては少なすぎたの か，この点に関しては今後検討を加えてみる必要がある ようだ。

今回 dextran 投与後 6 時間目の 血清を電気泳動用の サンプルに選んだのは，第 4 群が 6 時間目附近で一番高 い活性を示した事, また他の群もこの附近でほぼピーク を形成した事より考它最も適当と判断した為である。

Cortisone acetate がこの実験系に於いても $\beta$-glucuronidase の場合と同様な stabilizer 作用を示した事 は今後に残された問題であろう。

以上今回の実験結果を考按してきたが，著者は腎由来 の醥素（特に LDH）を検討する事により，抗生㓮によ る腎毒性の発現を早期に認知出来るのではないかと考兄 ている. 今回の実験では投与量，投与期間，また脱水以 外の実験条件等，まだまだ検討を要する所は多々ある が，血中 LDH の検討により，今日まで一般的に行なわ れている腎機能検査より簡単に腎障害の発現を認知しう る方法が探究出来るのではないかと考えている.

\section{結語}

Kanamycin， dextran 併用時にみられる急性腎不全 について生化学的方法論を用いて検討した. 腎皮質部分 の lysosomal enzyme の代表として $\beta$-glucuronidase を，血清に遊離する cytoplasmic enzyme としてLDH を選び，両者の活性の変化について観察すると同時に， 血清 LDH そついてはその isoenzyme を，DEAE一七 ルローズを用いるHess の方法怙よび電気泳動を用いて その pattern に検討を加えた。

（1） lysosomal membrane より機械的破壊により 上清部分に遊離した該酵素活性を測定した。一番強い活 性を示したのは, kanamycin, dextran を併用した第 4 群で, 次いで第 5 群, 3 群, 2 群, 1 群の順であつた。 第 4 群と第 5 群の間には推計学上有意の差を認めたが, 第 5 群， 3 群， 2 群の間にはそれは認められなかつた。 脱水のみ活どこした第 1 群とその他の群の間には明膫な 差を認めた。
さらに lysosomal fraction $に 37^{\circ} \mathrm{C} 40$ 分の incubation を行ない該酵素の lysosomal membrane からの遊離に ついて検討を加えた. Incubation により一番多くの酵 素を遊離したのは第 4 群であつた。この実験に於いても 前記の傾向がより強く認められた。

(2) LDH について

血清中の LDH 活性は脱水のみではその活性に变化を 認めなかつたが dextran の投与により急速で一過性の 活性上昇を示した。これに対し kanamycin とdextran を併用した第 4 群では該酵素の活性は投与後少くとも 24 時間は高い值を示した. DEAE一セルローズにより肝蔵 型一LDH と腎蔵型—LDH を分画し, 腎蔵型—LDH の 肝蔵型一LDH に対する割合を経時的に検討したが，腎 臓型一LDH のしめる割合が第 4 群, 第 5 群で経時的に 増加している事が認められた。

Cortisone はこの割合には殆んど变化を与えなかつ た.

（3）電気泳動を用いて第 3 群，执よび第 4 群の isoenzyme を比較してみると, 第 3 群では $\mathrm{LDH}_{-5}$ の 大きなピークを明膫認めるがその他のピークは殆んど 認められなかつた。一方 kanamycin, dextran を併用 した第 4 群では $\mathrm{LDH}_{-1}$ より, $\mathrm{LDH}_{-5}$ までの 5 本のピー クを認めた。

以上の結果より kanamycin, dextran は単独に投与 された場合でもある程度の影響をlysosomal membrane に与光， $\beta$-glucuronidase を遊離させるが，両者を併 用した場合には相加，または相乗的作用を拉よぼす事 が判明した。また cortisone acetate は kanamycin, dextran のこの作用をある程度阻止するものと思われ る。また kanamycin, dextran の併用により血清 LDH 活性の上昇がみられる事が判明した。 その血清に遊離し た酵素の isoenzyme を検討した結果, 腎蔵型—LDH が経時的に増加し, この作用を cortisone がある程度阻 止する事を見出した。

今後この実験系を用いて, 種々の抗生剤の腎毒性の判 定法としての有用性の有無を検討したいと考えている.

本実験の要旨は 1969 年第 6 回国際化学療法学会及び 19 69 年第12回日本督臓学会に於て報告した.

最後に稿を終るに当つて終始御指導を戴いた大越正秋 教授, 生理学教室塚田裕三教授に, 深甚なる謝意を表す ると共に, 名出頼男講師初め研究室の諸见に深謝致しま す. 


\section{文献}

1) Schlegel, J.U. and Burden, J.J.: J. Urol. 91, 127, 1964.

2) Prát, V., Hatala, M. and Benešová, D.: Virchows Arch. Path. Anat. 339, 37, 1965.

3) Málek, P., Zástava, V., Žák, F., Kočvara, S.V. and Kolc, J.: J. Urol. 89, 784, 1963.

4) 大越正秋, 川村猛：日本医師会誌, 60, 999, 1968.

5) 大越正秋：日泌尿会誌，58，933，1967.

6）川村 猛：日泌尿会誌，60，555, 1969.

7) Bell, N.H., Androile, V.T., Sahasin, S.M. and Utz, J.P.: Am. J. Med. 64, 1962.

8) Takacs F.J., Tomkieweicz, Z.M. and Merrill, J.P.: Ann. Int. Med. 59, 716, 1963.

9) Butler, W.T.: Ann. Int. Med. 61, 175, 1964.

10) Wertlake, P.T.: J. Lab. Clin. Med. 7, 472, 1967.

11) Bryer, M.S., Schoenbach, E.B. and Lang, P.H.: Ann. New York Acad. Sci. 51, 935, 1949.

12) Schoenbach, E.B., Bryer, M.S. and Lang, P.H.: Ann. New York Acad. Sci. 51, 987, 1949.

13) Jawetz, E.: Am. J. Med. 10, 111, 1951.

14) Moyer, J.H., Mils, L.C. and Yow, E.M.: Arch. Int. Med. 92, 238, 1953.

15) Schreiner, G.E. and John, F.M.: Ann. J. Med. 38, 409, 1965.

16) Petersdorf, R.G. and Hook, E.W.: Bull. Johns Hopkins Hosp. 107, 133, 1960.

17) Wright, W.W. and Welch, H.: In Antibiotics Annual: 1959-1960 Proceedings of the seventh Annual Symposium on Antibiotics. pp 1034 New York, Antibiotics 1960 pp61.

18) Wolinsky, E. and Henis, J.D.: New England J. Med. 266, 759, 1962.

19) Allen, A.C.: Medical and Surgical Disease, 2nd ed. New York, 1962. Grune and Stratton.

20) Winfield, M., Crisp, G.O., Maxwell, M.H. and Kleeman, C.R.: Ann. New York Acad. Sci. 76, 140, 1958.

21) Berman, L.B. and Katz, S.: Ann. New York Acad. Sci. 76, 149, 1958.

22) Kleeman, C.R. and Maxwell, M.H.: In: Biology of pyelonephritis Edited by Quinn, E.L. and Kass, E.H. Boston, 1960. Little, Brown \& Co.

23) Karlson, A.G., Gainer, U.H. and Feldman, W.H.: Am. Rev. Turberc. 62, 345, 1950.

24) Wasbren, B.A. and Spink, W.W.: Ann. Int. Med. 33, 1099, 1956.

25) Jao, R.N. and Jackson, G.G.: JAMA 189, 817, 1964.

26）上田 泰, 他：Chemotherapy 15, 275, 1967.
27）上田 泰: Chemotherapy 14, 484, 1966.

28) 古屋暁一, 三沢 就: Chemotherapy 14, 506, 1966.

29）木下康民，他：最新医学， 23，1490，1968.

30) 加藤繁次, 神野一, 宇都宮利善, 山村武夫 : 第16回化学療法学会総会

31）桜井叢人, 伊藤本男：日泌尿会誌, 60,90 , 1969.

32）赤坂 裕，他：日泌尿会誌，60, 706, 1969.

33）木村茂三：日腎会誌，11，605, 1969.

34) Morgan, T.O., Little, J.M. and Evans, W.A.: Brit. Med. J. 2, 737, 1966.

35) Mailloux, L., Swartz, C.D., Capizzi, R., Kim, K.E., Onesti, G., Ramirez, O. and Brest, A.N.: New England J. Med. 277, 1113, 1967.

36) 百瀬俊郎：日泌尿会誌，60,823, 1969.

37）木下康民，山作房之輔，三上朝芳，大沢源吾, 和田十次, 武田 元, 江部達夫：日腎会誌, 11, 209, 1969.

38) Trump, B.F. and Janigan, D.T.: Lab. Invest. Med. 11, 395, 1962.

39) Maunbach, A.B., Madden, S.C. and Latta, H.: Lab. Invest. Med. 11, 421, 1962.

40) Hazama, S.: Acta Path. Jap. 14, 461, 1964.

41) Shibko, S. and Tappel, A.L.: Biochem. J. 95, 731, 1965.

42) Weissmann, G. and Thomas, L.: J. Exp. Med. 116, 433, 1962.

43) Fishman, W.H., Springer, B. and Brunetti, R.: J. Biol. Chem. 173, 449, 1948.

44) Bergmeyer, H.U., Bernt, E. and Hess, B.: In: Methods of enzymatic analysis. pp 736. Academic Press New York and London 1965.

45) Hess, B.: Ann New York Acad. Sci. 94, 890, 1961.

46) 菅野剛史 : in preparation

47) Tisch, D.E., Huftalen, J.B. and Dickson. H.L.: Ann. New York Acad. Sci. 76, 44, 1958.

48) Welch, H., Wright, W.W., Weinstein, H.I. and Staffa, A.W.: Ann. New York Acad. Sci. 76, 66, 1958.

49) 木下浩二 : 広島医学, 7, 1029, 1959.

50) Kuntz, E.: Klin. Wechschr. 40, 830, 1962.

51) Grönwall, A. and Ingelman, B.: Acta Physiol. Scand. 7, 97, 1944.

52) Ingelman, B.: Acta Chem. Scand. 1, 731, 1947.

53) Arturson, G., Granath, K., Thoren, L. and Wallenius, G.: Acta Chir. Scand. 127, 543, 1964.

54) Harrison, J.H.: Ann. Surg. 139, 137, 1954.

55) Terry, R., Yuile, C.L., Colodetz, A., Clay, E.: J. Lab. Clin. Path. 42, 939, 1947. 
56) Gray, I., Süteti, P.K. and Pulaski, E.J.: Soc. Exper. Biol. Med. 17, 626, 1953.

57) Gray, I., Süteri, P.K. and Pulaski, E.J.: J. Physiol. 174, 426, 1953.

58) Johston, E.V., Lundy, J.S., Bennett, W.A. and Jones, J.M.: Amer. J. Surg. 85, 720, 1953.

59) Zettergren, L.: Acta Chem. Scand. 123, 439, 1962.

60) Vickery, A.L.: Amer. J. Path. 32, 161, 1956.

61) Traenckner, K.: Frankfurt Z. Path. 65, 390, 1954.

62) 小島瑞, 高橋潔, 笠島武, 本田憲児：日網会誌 7, 207, 1967.

63) Schöll, A.B.: Frankfurt Z. Path. 73, 559, 1964.

64) de Duve, C., Pressman, B.C., Gianetto, R., Wattiaux, R. and Appelmans, F.: Biochem. J. 60, 604, 1955.

65) Gianetto, R. and de Duve, C.: Biochem. J. 59, 433, 1955.

66) Wattiaux, R. and de Duve, C.: Biochem. J. 63, 606, 1956.

67) Beaufay, H. and de Duve, C.: Biochem, J. 73, 604, 1959.

68) Lucy, J.A., Dingle, J.T. and Fell, H.B.: Biochem. J. 79, 500, 1961.

69) de Duve, C., Wattiaux, R. and Wibo, R.: Biochem. Pharmacol. 9, 97, 1962.

70) Dingle, J.T.: Ciba Foundation Symposium on Lysosomes, pp 384. Churchill London.

71) Dingle, J.T., Sharman, I.M. and Moore, T.:
Biochem. J. 98, 476, 1966.

72) Ishii, T., Ishii, D. and Balogh, K. Jr.: Acta Otolaryng. (Stockh.) 65, 449, 1968.

73) Koenig, H. and Jibril, A.: Biochem. Biophys. Acta 65, 543, 1962.

74) Weissman, G. and Dingle, J.T.: J.Exp. Med. 116, 433, 1961.

75) Weissmann, G. and Thomas, L.: J. Clin. Invest. 42, 661, 1963.

76) LaDue, J.S., Wroblemski, F. and Karmen, A.: Science 120, 497, 1954.

77) Nydick, I., Wroblewski, F. and LaDue, J.S.: Circulation 12, 161, 1955.

78) Kemp, E.: Acta path. microbiol. Scand. 45, 7, 1959.

79) White, L.P.: New England J. Med. 255, 449, 1956.

80) Wacker, W.E.C., Ulmer, D.D. and Vallee, B.L.: New England J. Med. 255, 449, 1956.

81) West, M. and Zimmermann, H.J.: J. Lab. Cli. Med. 52, 185, 1958.

82) Kemp, E. and Laursen, T.: Acta path. microbiol. scand. 54, 85, 1962.

83) Nielsen, V.K., Kemp, E. and Laursen, T.: Acta med. Scand. 184, 109, 1968.

84) West, G.B. and Harris, J.M.: Ann. New York Acad. Sci. 118, 441, 1964.

85）松本普三, 長友淳彦, 塩崎秀司, 渡辺盛雄, 小 宗大三郎, 竹谷明, 柏崎修, 小関裕: フレルギ - , 18, 58, 1969.

（1970年 7 月 6 日受付） 